\title{
Piotr Gorzelańczyk
}

Stanislaw Staszic University of Applied Sciences in Pila e-mail: piotr.gorzelanczyk@puss.pila.pl

ORCID: 0000-0001-9662-400X

\section{Wojciech Górniak}

Stanislaw Staszic University of Applied Sciences in Pila e-mail: gorniak-wojtek@op.pl

ORCID: 0000-0003-3397-5413

\section{ASSESSMENT OF TECHNICAL CONDITION OF FORKLIFT TYRES USED IN INTERNAL TRANSPORT BY STUDYING DAMAGES AND OPERATING CONDITIONS}

\section{OCENA STANU TECHNICZNEGO OPON WÓZKÓW WIDŁOWYCH WYKORZYSTYWANYCH W TRANSPORCIE WEWNECTRZNYM}

DOI: 10.15611/nit.2019.2.03

JEL Classification: R41

\begin{abstract}
With the invention of the tyre, no one could have foreseen that over time it would perform such an important function, and without it industry, and everyday life would look completely different. Over time, the use of such an important innovation has created new challenges to be faced. Over the entire lifespan of the tyre, it gradually wears out or is suddenly damaged. An important issue is the ability to predict the remaining lifetime or eliminate any damage that may pose a threat in its further use. The aim of the article is to determine the technical condition of tires used in the selected company, by determining their age, damage, possibility of further use and those which should be withdrawn from service. The first part of the article presents the characteristics of forklift tyres, showing their construction, advantages and disadvantages, and the most common damage. Then the internal transport in which the forklift is used is characterized. In the next, main part of the article, the tyres of forklifts were examined, and the results and analysis of the measurements carried out were presented. The paper provides conclusion that arose during the performance of tests and solutions for users of the tested tyres.
\end{abstract}

Keywords: technical condition, tyres, forklifts, transport means.

Streszczenie: W chwili powstania pierwszej opony nikt nie był w stanie przewidzieć, że wraz z upływem czasu będzie ona pełnić tak ważną funkcję w życiu. Gdyby nie ona, przemysł, życie codzienne i praktycznie wszystko, co nas otacza, wyglądałoby zupełnie inaczej. 
Z czasem eksploatacja tego ważnego elementu stworzyła nowe wyzwania, z którymi należało się zmierzyć. Opona w całym okresie swojego życia ulega stopniowemu zużyciu bądź nagłemu uszkodzeniu. Istotną kwestią jest umiejętność przewidywania pozostałego czasu eksploatacji bądź eliminacja uszkodzeń, które stanowią zagrożenie przy dalszym jej użytkowaniu. Z tego powodu w artykule dokonano oceny stanu technicznego opon wózków widłowych wykorzystywanych $\mathrm{w}$ transporcie wewnętrznym. W pierwszej części artykułu przedstawiono charakterystykę ogumienia wózków widłowych, omawiając ich budowę, zalety, wady i najczęściej występujące uszkodzenia. Następnie scharakteryzowano transport wewnętrzny, w którym jest wykorzystywany wózek widłowy. Zbadano ogumienie wózków widłowych, przedstawionojego wyniki oraz zaprezentowano analizę wykonanych badań pomiarowych. Artykuł kończą wnioski z badań oraz propozycje rozwiązań dla użytkowników badanych opon.

Słowa kluczowe: stan techniczny, ogumienie, wózki widłowe, środki transportu.

\section{Characteristics of internal transport}

Internal transport involves handling, packaging and storage of materials in any form in the plant area. This issue is also related to internal transport technology, which is the way of transport and storage resulting from the logistics task of the plant (Gorzelańczyk and Sikora, 2019).

There are various means of transport used in every form of internal transport. Assuming that the most desirable features of the means of transport are the unlimited area of activity and the ability to implement a full transport cycle, it is concluded that the most suitable means of internal transport are lift trucks and forklifts. Pallet trucks are used for the horizontal transport of loading units, where one can distinguish among them: mechanically steered (in the operator's standing position, sitting and without the operator) and mechanically and manually guided. From the point of view of the subject discussed, the most important element of internal transport are forklifts (Gorzelańczyk and Sikora, 2019; Tire marking, n.d.; What are the different winter tires..., n.d.). The Figure 1 presents the design of the most popular front-lift forklift.

A typical forklift consists of the running gear, i.e. drive, wheels, steering, braking, and the executive system which includes the forks and hydraulic system. Nowadays, there are three and four-wheeled varieties, which affects the basic operating parameters such as: nominal capacity, range, speed, and the ability to tackle hills. These are the types of structures that can be equipped with a drive (Gorzelańczyk and Sikora, 2019):

- electric

- combustion,

- exhaust gas with liquefied gas installation,

- hybrid (electric-combustion),

- a hydrogen cell. 


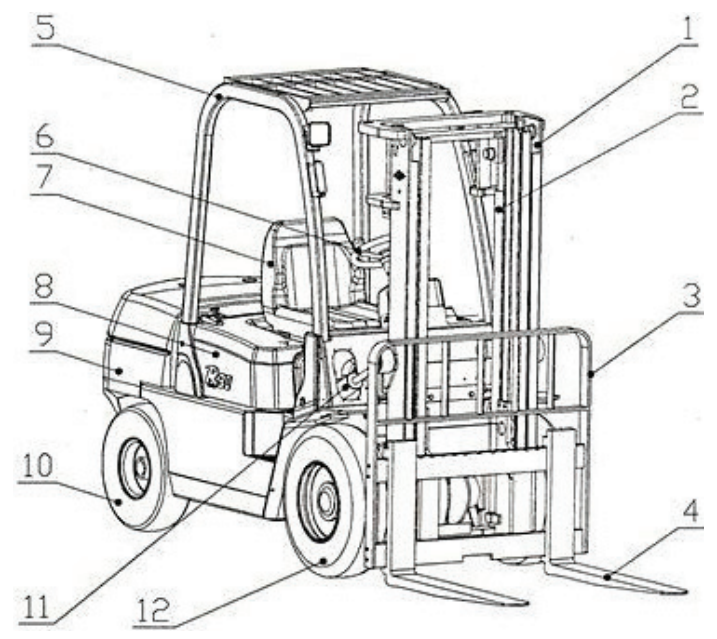

1 - truck mast, 2 - lifting cylinder,

3 - carriage, 4 - forks, 5 - safety frame,

6 - steering wheel, 7 - operator's seat,

8 - engine cover, 9 - counterweight,

10 - rear wheel, 11 - tilt cylinder,

12 - front wheel

Fig. 1. Forklift

Source: (Tire marking, n.d.).

For the forklift to function properly, it must be properly tyred. The advantage of super-elastic tyres is its puncture resistance reducing its shock-absorbing properties. Therefore, trucks with such tyres should operate on even and hard ground. In order to work in poorer operating conditions, one should use pneumatic tyres. The correct selection of tyres for the forklift truck is very important As the incorrect choice may result in a significant reduction in the operating time as well as generate hazardous situations during operation. The main hazards contributing to accidents are associated with improper operation, with the operation of equipment, as well as non-compliance with health and safety regulations (Gorzelańczyk and Sikora, 2019; Tire damage operational defects, n.d..; Tire marking, n.d.; What are the different winter tires..., n.d.).

\section{Truck tyres}

The first pneumatic tire was a flexible tube filled with compressed air. It was created by R.W. Thomson and consisted of a ring made of rubber fabric and an outer jacket made of leather (Guzik and Suchecki, 1991). Initially, the market showed no demand for this type of invention and it had to wait about 50 years to be used by the Michelin brothers in the wheels of the car. The real revolution came in 1839, when C. Goodyear developed the process of vulcanization. From now on, tires made entirely of rubber were used. In 1845, Thomson patented the idea of inflating tyres instead of using solid rubber tyres. Initially, this idea did not find enthusiasts and it was only in 1888 when J. Dunlop produced the first pneumatic tyre. After initial difficulties, progress in the field of tyres began to accelerate. At the end of the 19th century, the brothers Eduard and Andre Michelin introduced the first convertible tire model. The construction used allowed for replacement in less than 15 minutes. In 1889, J.F. Palmer introduced cord to the tire structure, whereas in 1907 the Hometron Tire 
and Rubber Co. applied the world's first tread. At that time, the actual tyre structure was fully formed, and afterwards it was only being modernized. In 1928 the first tyre factory in Poland "Stomil" opened in Poznań (Andrzejewski, 2010; Guzik and Suchecki, 1991).

Forklift tyres are a very important element, as they ensure safety when moving and transporting heavy goods and during their stationary lifting, whilst ensuring comfort of using transport vehicles. The design of such a tyre must meet all these requirements, while providing the possibility of long-term use.

The activities such as starting off, accelerating, turning and braking are carried out by tyres, their most important tasks are to ensure (Tire production, n.d.):

- possible high friction forces in various road situations,

- high transmission efficiency (low rolling resistance),

- good insulation of vibrations generated by uneven ground,

- high durability and reliability throughout the entire service life.

Forklift trucks usually use two basic types of tyres: super-elastic and pneumatic. The former (Figure 2) are used because of the need for high stability and also in places where there is a high risk of puncture or damage (e.g. high temperature) and high pressure. This type of tyres increases the stability of the vehicle, especially important at high-level storage. In this type of tyres, their puncture and damage is virtually eliminated, thus increasing the mobility. The super-elastic tire has a special rubber layer in the construction responsible for bending, thanks to which the ride comfort is similar to a pneumatic tire.

Fig. 2. Construction of a super-elastic tire Source: (Warecki, n.d.).

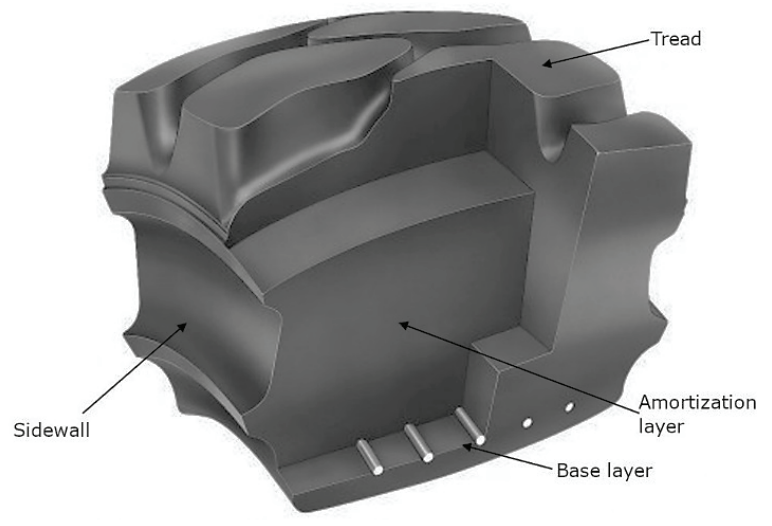

Pneumatic tyres (Figure 3) come in two variants: diagonal and radial. Pneumatic tires are used where there is no risk of damage to the tyre structure or it is minimal. They is created by arranging several layers of cord alternately in two directions at different angles than $90^{\circ}$. With this design, higher stiffness is obtained than in radial tires. The diagonal construction has advantages and disadvantages with respect to the radial tire design (Andrzejewski, 2010). 
The advantages are:

- ensuring better driving comfort,

- greater resistance to mechanical damage.

The disadvantages are:

- greater angular deformations, and greater lateral drift angles, which makes driving less precise,

- increased rolling deformation, which results in higher fuel consumption.

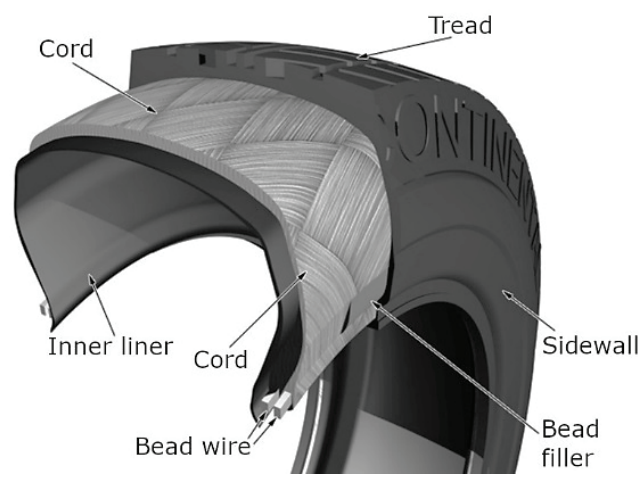

Fig. 3. Construction of the diagonal tire Source: (Warecki, n.d.).

The tyre shown in the above figure consists of the following components (Tire markings..., n.d.; Tire defects - operational damage, n.d.):

- The tread is designed to ensure adequate adhesion of the tire to the road surface, while ensuring a sufficiently low level of abrasion. It is usually made of a mixture of different rubbers, depending on the purpose of the tire. This also affects the shape of the tread.

- The warp is the basic load-bearing element. It consists of several layers of cord fabric, arranged at different angles depending on the type and design of the tire. To increase the cohesion of individual layers and reduce internal friction, a rubber layer is used between them. Steel, polyamide, polyester, viscose and fiberglass are used for the cord.

- The sides of the tire provide adequate tire flexibility, both when driving on uneven roads and when cornering. The rubber in this zone must protect the lateral structure from damage and must also be resistant to fatigue by dynamic loads.

- The cap is a layer of rubber inside the tire that acts as a seal and covers the inner surface of the tire. In tubular tires, it provides protection against wear of the tube against the warp fibers, while in tubeless tires, it ensures tightness.

- The wire is a weave of steel wires giving the foot stiffness in the circumferential direction. Appropriate design ensures correct positioning of the foot on the wheel disc.

Another variant of these tires is the radial tire (Figure 4). It was created by a radial arrangement of the warp cord, which increases the flexibility of its side. By using several layers of strapping, one obtains a stiffening of the tire face. This design 
solution increases the contact area between the tire and the road. Compared to the diagonal tire, one obtains smaller angular deformations, lower rolling resistance and lower resistance to mechanical damage (Jaworski, 1987; Tire defects - operational damage, n.d.; Tire markings..., n.d.)

Fig. 4. Construction of the radial tire

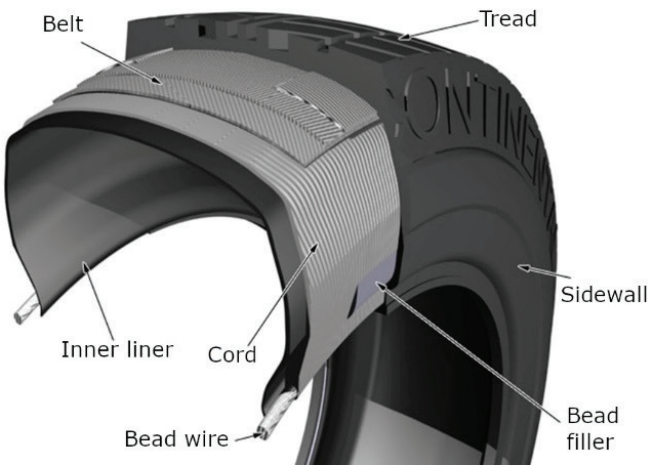

Source: (Warecki, n.d.).

A number of components of both types of tires have been described earlier, for this reason only significant, different components of the radial tire are approximated as follows (Tire defects - operational damage, n.d.; Tire markings..., n.d.):

- The tire shoulder is made of a rubber compound with good heat transfer properties, which translates into discharging it into the atmosphere. The shoulder is involved in the transfer of grip forces when driving on snowy dirt roads.

- The belt is used to stiffen the face of the tire, thus resulting in better adhesion of the tire to the road surface. In the radial tire one can distinguish: external and internal strapping. External strapping is created by using two layers of polyamide cord, while internal strapping is created by using two layers of steel cord. All cord fibers are arranged in relation to each other at an angle of $70^{\circ}$ to $85^{\circ}$. This means to obtaining two adjacent layers of cord at intersecting angles, which ensures high rigidity of the tire face.

- The carcass is the basic load-bearing element of the tire. In its construction it connects all tire zones, i.e. the tread face, tire shoulder, tire sidewall, rim and bead. The carcass design transfers the drive torque and braking torque as well as the remaining forces loading the tire. They may come from the loading weight or even from the uneven ground on which the vehicle is moving. In radial tires, the matrix material depends on its subsequent use, so textile fibres are used in passenger cars, while steel fibers are used in trucks.

- The chafer performs the function of stiffening the tire foot. It is made of a layer of steel cord covered with rubber, and is only available in radial tires.

A properly used tire is subject to even wear across the entire width and circumference of the tread. The amount of the defects in the material of a tire depends on many factors that constantly affect its entire service life. The tire defects are 
affected by their wear i.e. abrasive, adhesive, fatigue, thermal and as a result of ageing (Jaworski, 1976). During improper use of the tire, uneven wear occurs in its various areas indicating the reason for this. Regardless of the occurring damage, such as clear one-sided tire tread wear, clear one-sided or double-sided wear on the shoulder of the tire, clear wear in the center of the tire, tire wear, circumferential tire damage, cut damage, tire breakage as a result of impact, cut damage (on the side of the tire), of which the most important are those that reduce the tread or lose the continuity of the tire coating. At that time it is not possible to continue to use it, therefore such damage will not have a major impact on driving parameters. On the other hand, defects in the tread will directly translate into how the driven vehicle behaves (Tire defects, n.d.).

Therefore, constant supervision over the state of the tires is very important. Such activities should be carried out systematically and with due diligence, as this will translate into the safe use of the vehicle.

The problem of operating means of transport related to their safety was discussed in (Gorzelańczyk, 2012, 2016a, 2016b, 2017; Gorzelańczyk and Kaczmarek, 2019; Gorzelańczyk and Michaś, 2019; Gorzelańczyk and Sikora, 2019; Wachowiak, Gorzelańczyk and Kalina, 2018).

\section{Research}

The general technical condition of forklifts during everyday use is very important. The element connecting the trolley with the storage space is its tires. Its condition should be systematically verified and be good enough to ensure safety during use.

The subject of the research concerns pneumatic tires of all forklifts used in internal transport in the tested manufacturing company (Figure 5). They function in the unloading, transshipment and loading process as well as during the movement of materials within the warehouse. The tested tires work in partially closed warehouse conditions, i.e. part of the work is carried out inside and outside of the warehouse.

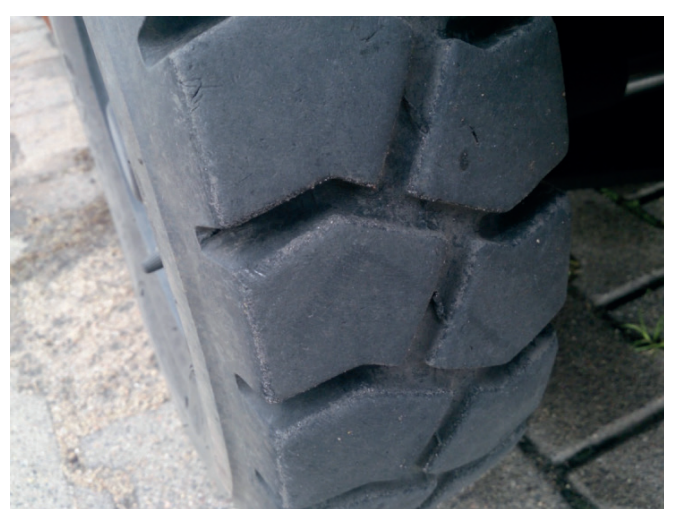

Fig. 5. Test object

Source: photo taken by the author. 
Each of the tested tires was subjected to a visual inspection test and tread height measurements. During the visual inspection examination, all types of damage to the tire were searched for and the age of the tires was determined. In addition, tread depth was tested using a universal caliper. The measurement was performed in four places around the circumference of the tire (every 90 degrees, points 1 to 4) (Figure 6), where the tread depth was read on the tread face in its recess, and the average results are presented in the table and in the figure below. The tested objects did not have the TWI (Tread Wear Indicator) indicator, therefore it was not used for the measurements.

Fig. 6. Location of tread depth measuring points

Source: photo taken by the author.

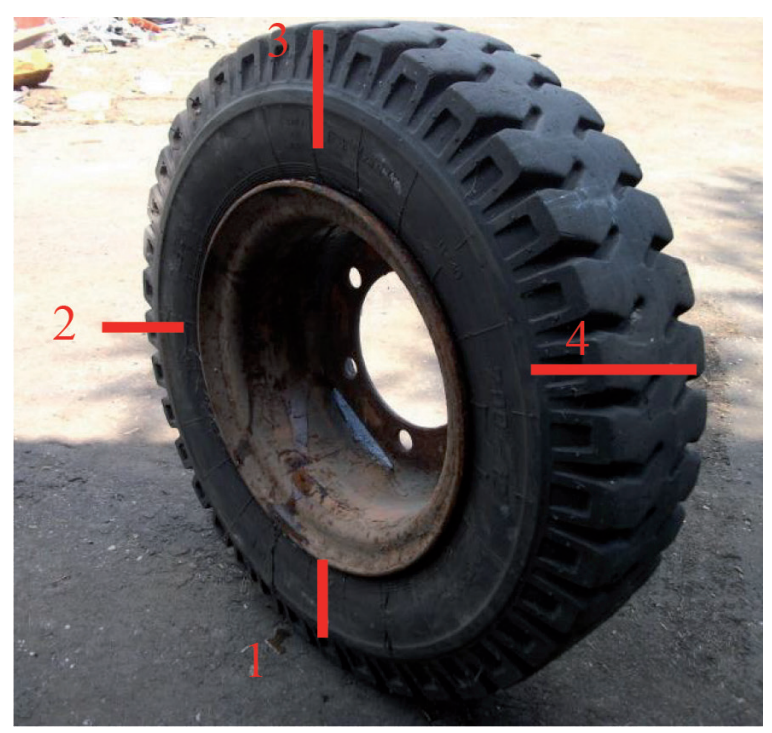

The age of each tire is written at the end of the DOT number as well as on its sidewall. The DOT number is a string of 7 to 12 characters that indicates the batch of tires manufactured in a given factory. The last four digits of this code (usually located on the border) contain information about the date of the tire's production. For example - 4208 means week 42 of 2008. For tires manufactured before 2000, there was a different designation and, for example, the numbers 228 could mean 22 weeks in 1998 or 1988. By contrast, in the 1990s an additional triangle appeared.

Based on the above table, one can conclude that the average tread wear of functioning tires is quite diverse. The examined objects came from 1997-2012. The values obtained in relation to the production year do not provide an unambiguous answer to the question: does their consumption depend on the year? It is more likely that consumption depends on the level of intensity of use. 
Table 1. Production date and average tread depth of tested tires

\begin{tabular}{|c|c|c|}
\hline Ordinary number & Production date & Average tread depth \\
\hline 1 & 0109 & $9.7 \mathrm{~mm}$ \\
\hline 2 & 0702 & $4.8 \mathrm{~mm}$ \\
\hline 3 & 1211 & $3.2 \mathrm{~mm}$ \\
\hline 4 & 0409 & $6.7 \mathrm{~mm}$ \\
\hline 5 & 4703 & $0.0 \mathrm{~mm}$ \\
\hline 6 & 4102 & $2.0 \mathrm{~mm}$ \\
\hline 7 & 228 (98 year) & $0.4 \mathrm{~mm}$ \\
\hline 8 & 447 (97 year) & $1.5 \mathrm{~mm}$ \\
\hline 9 & 0601 & $2.5 \mathrm{~mm}$ \\
\hline 10 & 2304 & $1.4 \mathrm{~mm}$ \\
\hline 11 & 3505 & $8.6 \mathrm{~mm}$ \\
\hline 12 & 178 (98 year) & $5.2 \mathrm{~mm}$ \\
\hline 13 & 089 (99 year) & $7.0 \mathrm{~mm}$ \\
\hline 14 & 1104 & $7.7 \mathrm{~mm}$ \\
\hline 15 & 1209 & $2.0 \mathrm{~mm}$ \\
\hline 16 & 4208 & $0.0 \mathrm{~mm}$ \\
\hline 17 & 4111 & $3.5 \mathrm{~mm}$ \\
\hline 18 & 1304 & $0.0 \mathrm{~mm}$ \\
\hline 19 & 2410 & $2.6 \mathrm{~mm}$ \\
\hline 20 & 2203 & $0.0 \mathrm{~mm}$ \\
\hline 21 & 2912 & $8.1 \mathrm{~mm}$ \\
\hline 22 & 3202 & $1.2 \mathrm{~mm}$ \\
\hline 23 & 2904 & $3.1 \mathrm{~mm}$ \\
\hline 24 & 3004 & $2.9 \mathrm{~mm}$ \\
\hline 25 & 1701 & $0.8 \mathrm{~mm}$ \\
\hline 26 & 3411 & $7.9 \mathrm{~mm}$ \\
\hline 27 & 2106 & $4.6 \mathrm{~mm}$ \\
\hline 28 & 4008 & $4.9 \mathrm{~mm}$ \\
\hline 29 & 1203 & $1.1 \mathrm{~mm}$ \\
\hline 30 & 2610 & $2.8 \mathrm{~mm}$ \\
\hline 31 & 3709 & $6.8 \mathrm{~mm}$ \\
\hline
\end{tabular}

Source: own calculations.

Figure 7 shows the current tread depth of the tires of the tested objects, and one can see that their diversity is very large. There are tires that have a tread depth at the level of the new tire, but there are also tires that have virtually no indentation. The obtained values should be related to the level of $1.6 \mathrm{~mm}$, which is the minimum permissible tread height above which the tire can be used; below this value, the tire should be taken out of service. At the beginning of use of the tires, all tires had the same tread height and were run for the same period of time. The red line in Fig. 8 shows this value. 


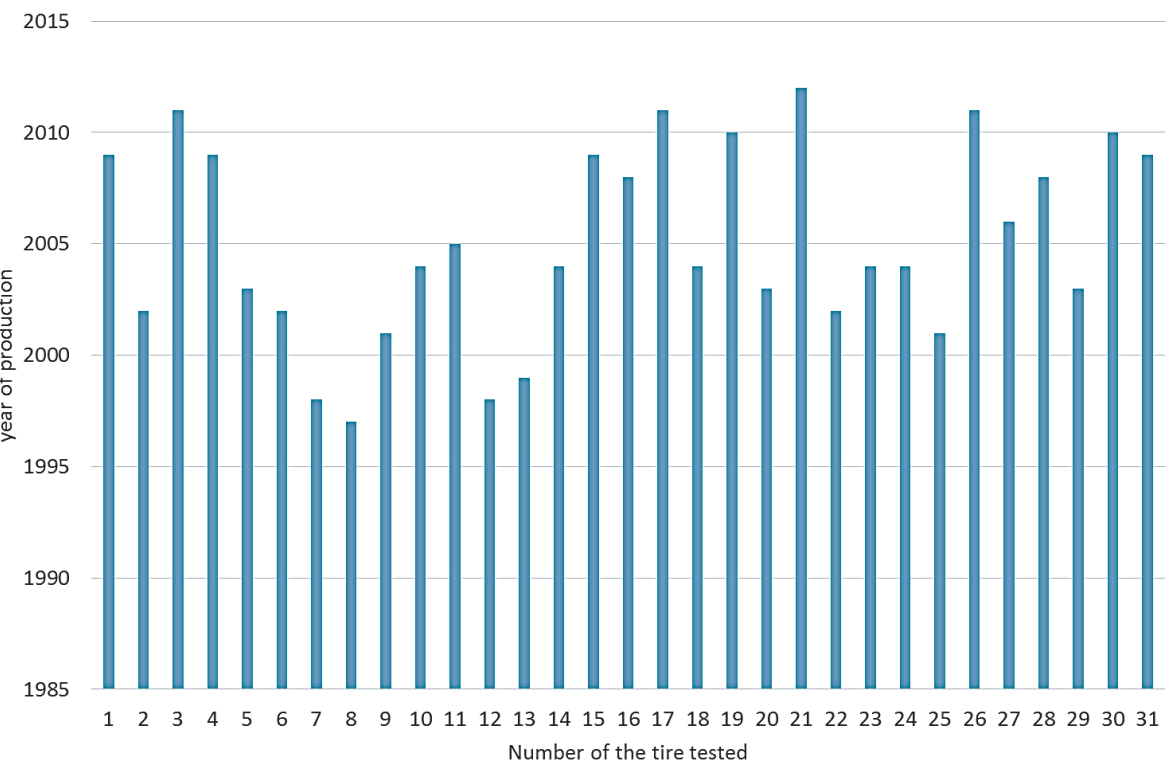

Fig. 7. Year of production of tested tires

Source: own calculations.

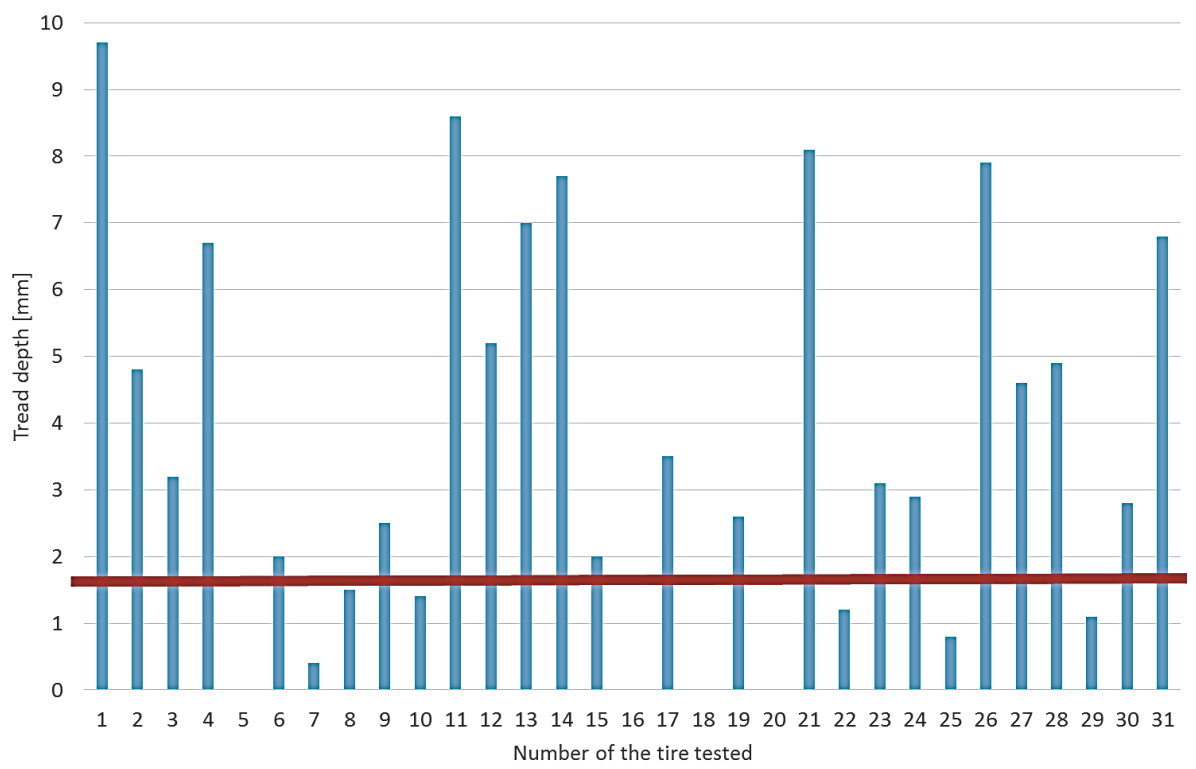

Fig. 8. Tread depth of tested tires

Source: own study. 
In addition to measuring the depth and determining the age of the tire, a visual inspection was also carried out, which showed the following damage.

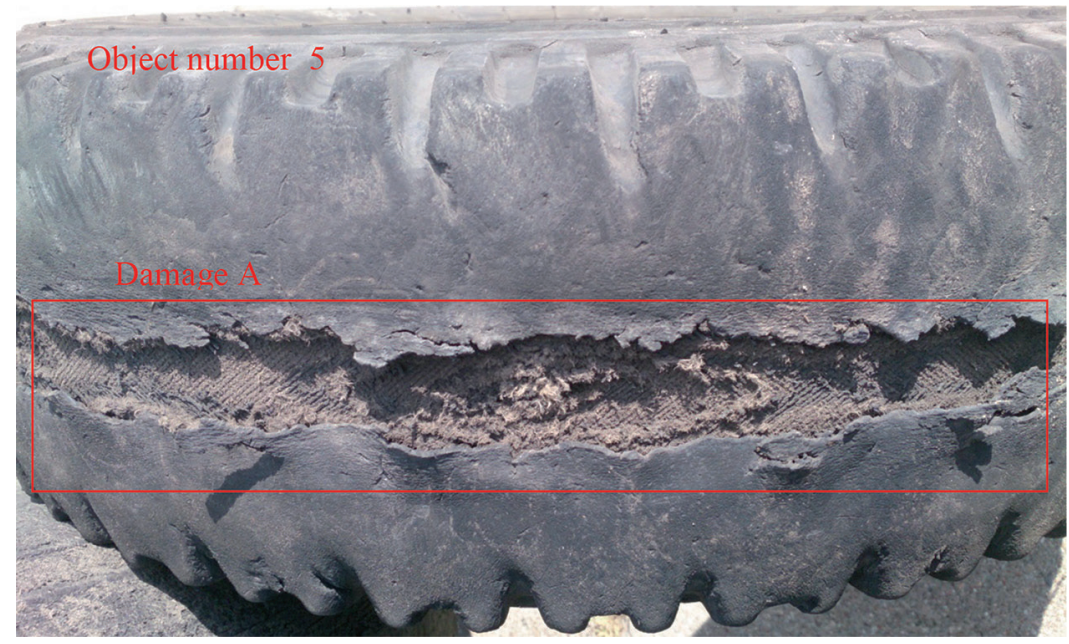

Fig. 9. Damage in object 5

Source: photo taken by the author.

At the test of object 5, very serious circumferential damage to the tire face can be seen, referred to as damage A.

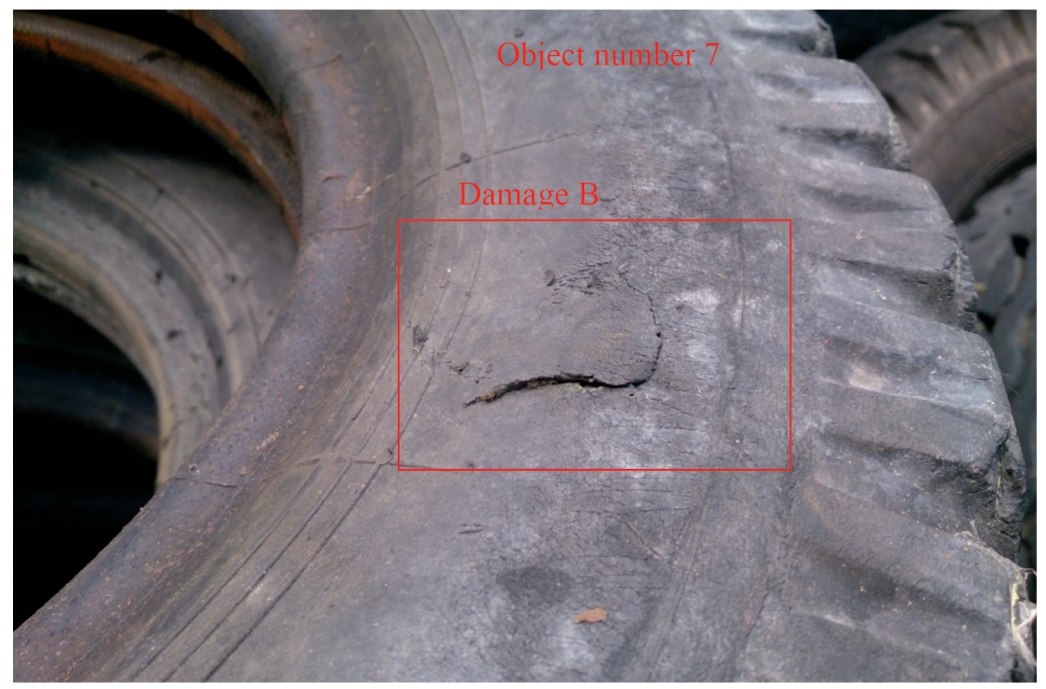

Fig. 10. Damage in object 7

Source: photo taken by the author. 
At the test of object 7, serious damage can be seen on the sidewall of the tire, later referred to as damage $\mathrm{B}$.

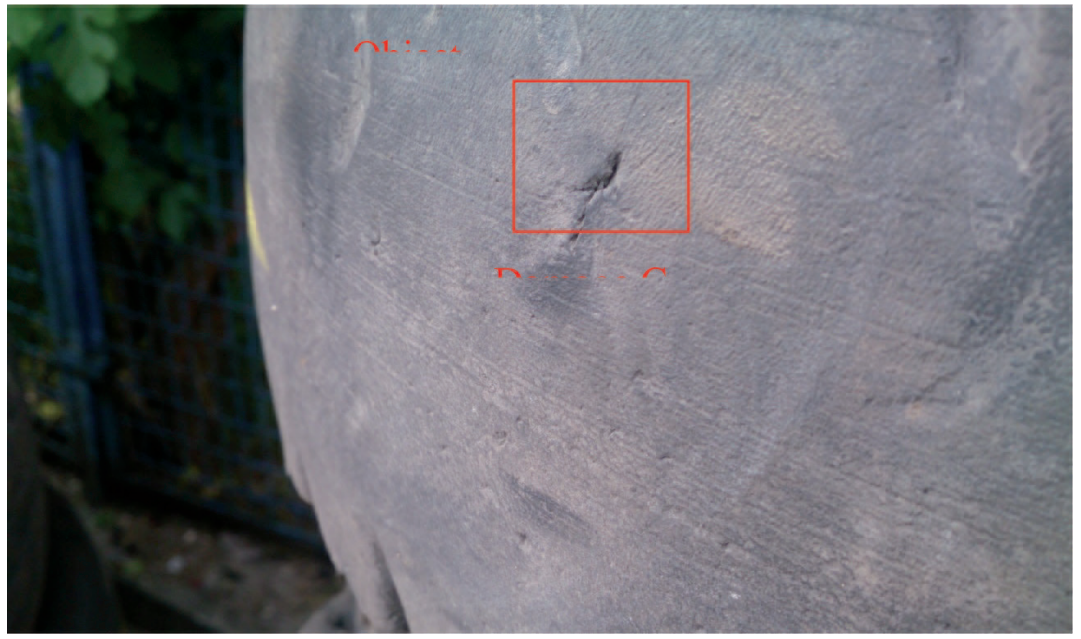

Fig. 11. Damage in object 16

Source: photo taken by the author.

At the test of object 16, a serious tire front puncture can be seen, later referred to as damage $\mathrm{C}$.

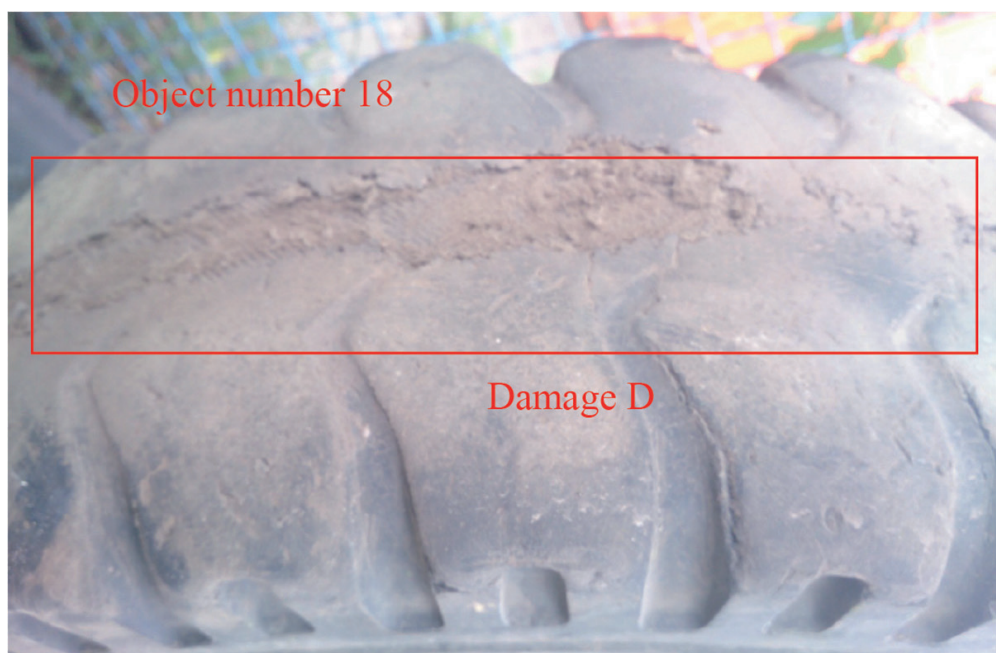

Fig. 12. Damage in object 18

Source: photo taken by the author. 
Very serious peripheral damage to the front of the tire can be seen at the test of no. 18 , later referred to as damage $\mathrm{D}$.

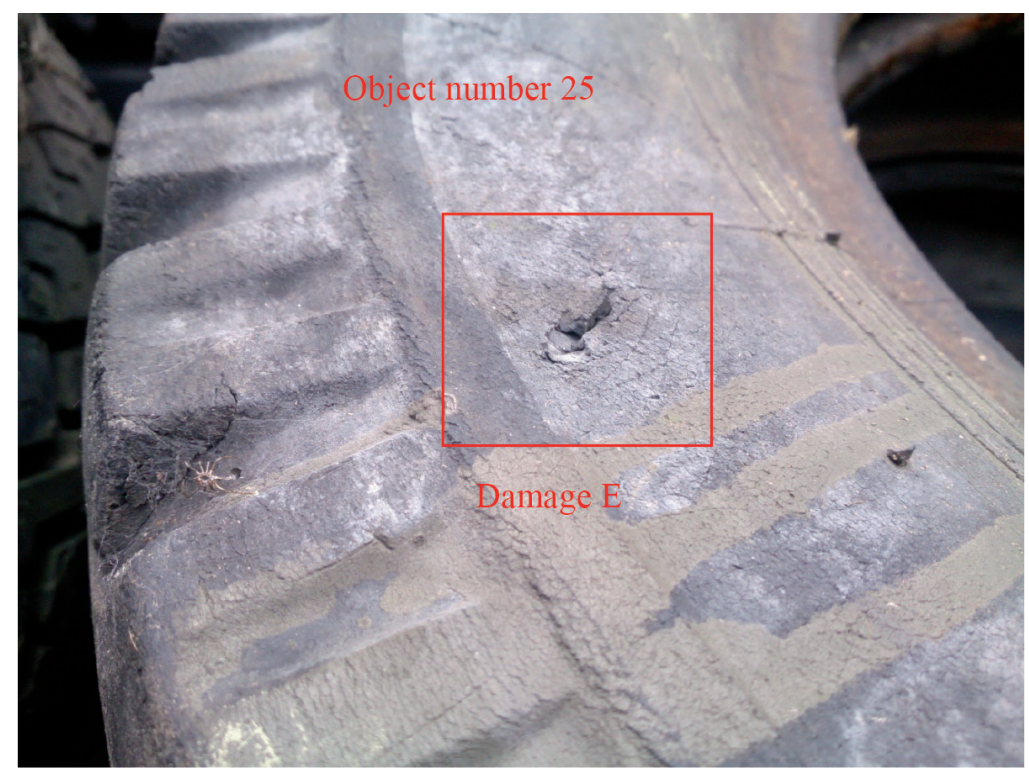

Fig. 13. Damage in object 25

Source: photo taken by the author.

At the test of object 16, a serious puncture can be seen in the side of the tire, later referred to as damage $\mathrm{E}$.

After measuring the tread depth and their visual inspection review, it was noted that some of the tested objects are in poor technical condition. Objects numbered: 5 , $7,8,10,16,18,20,22,25,29$ have an unacceptably low tread, which virtually eliminates them from further use. Moreover, objects numbered: 6, 9, 15, 19, 24, 30 are close to the maximum allowable tread wear, so one should consider removing them from further use in the near future. The tread height is closely correlated with the age of the tire, usually the older the tire, the smaller the tread. This is confirmed by the fact that the tires are operated in similar conditions.

The tested tires also had mechanical damage, which all occurred in the group of tires with a lower tread height than the allowable value. Object 5 had peripheral damage on the front, which was probably caused by the friction of the tire against a stationary forklift. On object 7 object one can see a significant burst on the sidewall of the tire. Such damage was probably caused by contact with a sharp solid element in the transport area. Object 16 has deep puncture damage located on its front which could have been created by a forklift driving onto a sharp element lying freely on its 
path. Total tire tread wear could also contribute to such damage. On object 18 one can see similar damage as with object 5 , which probably arose as a result of contact between the tire and the fixed part of the forklift. Object 25 has deep puncture damage on the side that may have arisen as a result of the tire being in contact with a sharp solid element in the transport area.

As one can see, there are several tires with severe damage in the test group. Additionally, there are also tires in a very good technical condition as seen below.

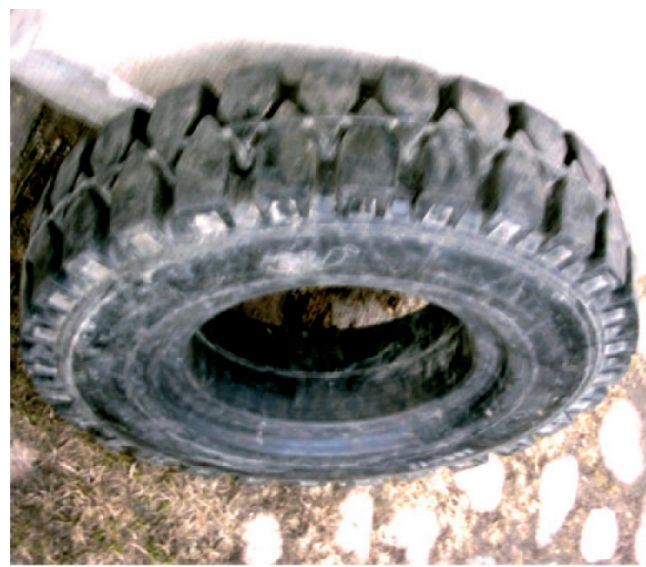

Fig. 14. Test object 13

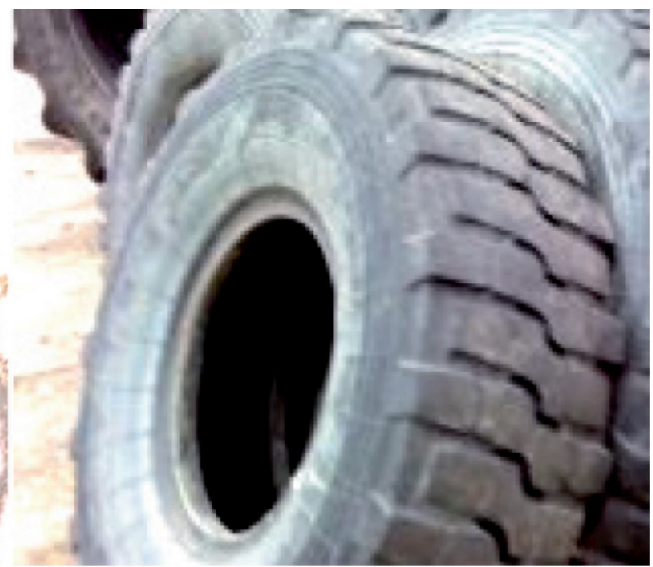

Fig. 15. Test object 12

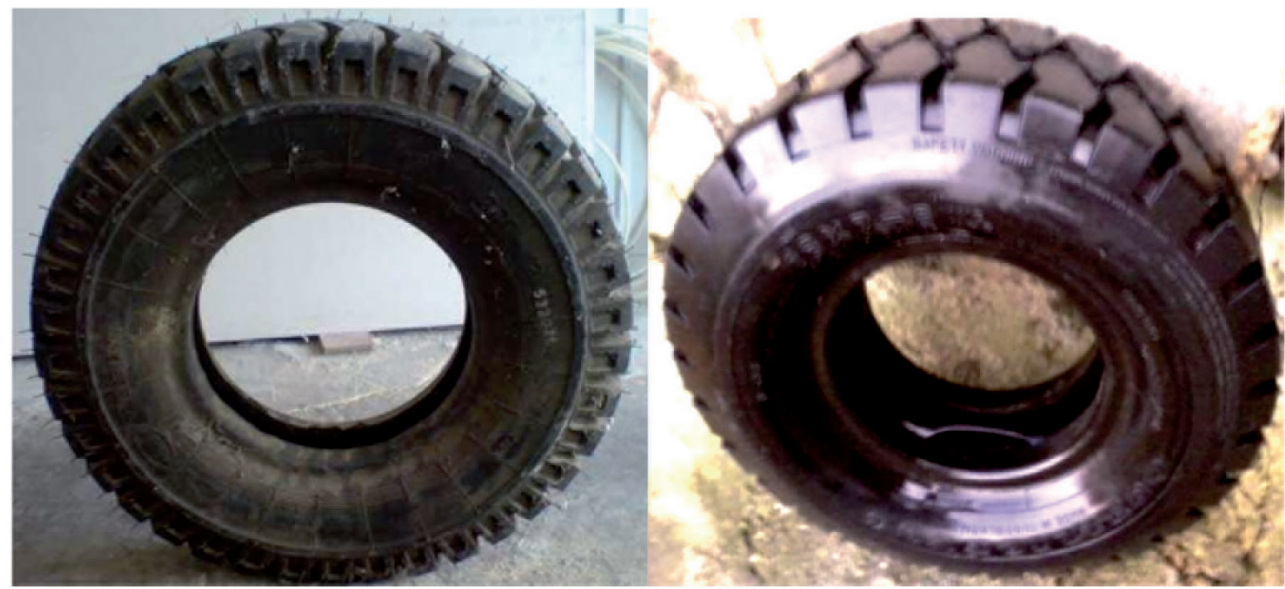

Fig. 16. Test object 1

Fig. 17. Test object 11

Source: photo taken by the author. 


\section{Conclusion}

After testing the forklift tires, the following conclusions can be made:

- All tested tires show tread wear.

- Some of the examined objects are not suitable for further use, as well as those that should be withdrawn from use in the near future.

- Damage A and D in object No. 5 and 18, eliminates them from further use. In addition, such damage should urge the technical inspection of forklifts. All solid parts of the vehicle that are probably in contact with the tire should be eliminated.

- Damage B, C and E on objects 7, 16 and 25 were caused by sharp elements in the transport area. Their further use is unacceptable, therefore they should be replaced as soon as possible. Persons driving forklifts in the transport area should pay particular attention to sharp elements located on the route of the forklift.

- Systematic technical reviews of means of transport should be introduced to avoid the tire tread being completely worn. When the tire tread of the forklifts is close to zero, dangerous situations can occur leading even to accidents, which directly endangers the driver of the forklift.

- Some of the tires have a fairly distant production date, which eliminates them from further use. The age of the oldest tire from the survey is 21 years, which should also be the reason for its withdrawal from further use.

- In the group of 31 tires tested, only 13 are in good technical condition.

\section{References}

Andrzejewski, R. (2010). Dynamics of the pneumatic road wheel. Warsaw: Scientific and Technical Publishing House.

Gorzelańczyk, P. (2012). Expert systems in the diagnostics of means of transport. Logistics, (3).

Gorzelańczyk, P. (2016a). Condition of paint coatings of vehicles operated in various climate zones. Buses. Technology, Exploitation, Transport Systems, (6), 871-875.

Gorzelańczyk, P. (2016b). Traffic noise emission testing in the city of Piła. Buses. Technology, Exploitation, Transport Systems, (6), 876-880.

Gorzelańczyk, P. (2017). Tire wear characteristics for public transport buses in the city of Piła. Buses. Technology, Exploitation, Transport Systems, (12).

Gorzelańczyk, P., and Kaczmarek, Ł. (2019). Impact of modern information systems on the operation of passenger vehicles. Buses. Technology, Exploitation, Transport Systems, (1).

Gorzelańczyk, P., and Michaś, D. (2019). Impact of Eco-driving on the operation of vehicles. Buses. Technology, Exploitation, Transport Systems, (1).

Gorzelańczyk, P., and Sikora, K. (2019). Technical and operational examination and analysis of mechanical and electric parking brakes. Buses. Technology, Exploitation, Transport Systems, (1).

Guzik, H., and Suchecki, B. (1991). Tires. Communication and Communication Publisher.

Jaworski, J. (1976). Rubber in motor vehicles. Warsaw: Communication and Communication Publisher. Jaworski, J. (1987). Tires for motor vehicles. Warsaw: Communication and Communication Publisher. Tire damage - operational defects. (n.d.). Retrieved August 20, 2018 from https://www.oponeo.pl/artykul/uszkodzenia-opon-usterki-eksploatacyjne 
Tire defects. (n.d.). Retrieved August 20, 2018 from http://www.netgum.pl/yszneenia.php

Tire defects - operational damage. (n.d.). Retrieved August 20, 2018 from http://www.opony.com.pl/ artykul/usterki-opon-uszkodzenie-eksploatacyjne/?id $=957$

Tire marking. (n.d.). Retrieved August 20, 2018 from http://www.opona.pl/p,inentenie-opon.html

Tire markings: How to read the markings on the tires, what are the indexes, how to recognize the size of the tire - all about tire symbols. (n.d.). Retrieved August 20, 2018 from https://www.se.pl/auto/ porady/oznaczenia-opon-jak-czytac-oznaczenia-na-oponach-jakie-sa-indeksy-predkosci-jak-rozpoznac-rozmiar-op-aa-eVca-XZxQ-jgoE.html

Tire production. (n.d.). Retrieved 20 August, 2018 from http://www.oponeo.pl/artykul/produkcja-opon Wachowiak, P., Gorzelańczyk, P., and Kalina, T. (2018). Analysis of the effectiveness of shock absorbers in light of applicable legal regulations in Poland and Slovakia. Buses. Technology, Exploitation, Transport Systems, (6).

Warecki, R. (n.d.). Radial and diagonal tires - how do they differ? Retrieved August 20, 2018 from https://autokult.pl/13268,opony-radialne-i-diagonalne-czym-sie-roznia-opony

What are the different winter tires with $M+S$ and 3PMSF marks? (n.d.). Retrieved August 20, 2018 from http://www.rezulteo-opony.pl/poradnik-opon-samochodowych/zimowe-opony/czy-oponym-s-to-opony-zimowe-1663 